\title{
はち蜜の水分の測定法について
}

\author{
慶田雅洋*1 白鳥つや子*2 川城 巌*1
}

\section{On the Determination of Water Content in Honey}

\section{Masahiro IWAIDA*1, Tsuyako SHIROTORI*2 and Iwao KAWASHIRO*1}

(*1 National Institute of Hygienic Sciences: 1-18-1, Kamiyoga, Setagaya-ku, Tokyo;

*2 Tokyo College of Domestic Sciences: 1-chome, Kaga, Itabashi-ku, Tokyo)

\section{まえがき}

はち蜜の水分の測定法としては A.O.A.C. 公定法1) には減圧乾燥法 (温度 $70^{\circ}$ 以下, $50 \mathrm{mmHg}$ 以下の減圧), および屈折計を使用する方法が定められている，後者 は，はち蜜の虽折率から 1 を引いたものは固形分と直線 関係を有するといら性質を利用したものであって， Chataway2)，Eckert 㧊よび Allinger3) 扤よび Torrent $^{4)}$ によって屈折率之水分の換算表が提出されてい る. A.O.A.C. ${ }^{1)}$ は Chataway2) の表を採用している。 Wedmore ${ }^{5)}$ はこれらの成績について詳細に検討した結 果, とくに水分の低いもの拈よび高いものでは測定例が 少なく, Chataway の表などの結果と必ずしも一致し ないことを認めて，新たに改訂表を作製した。この場合 の水分の計算は次式に上る（ただし R. I. : $20^{\circ}$ に拈け る属折率).

水分 $(\%)=\{\overline{1} .73190-\log ($ R. I. -1$)\} / 0.00243$

FAO/WHO によるはち蜜の暫定規格6) はこの Wedmore の表を水分の算出法として採用している.

わが国では，はち蜜の水分に関しては，規格化されて 捛らず，したがってその測定法についてもとくに定めら れていない，しかしながら近年食品としてのはち蜜の消 費が急激に増加している現状にかんがみて，はち蜜の水 分の統一的測定法を定めることが必要であると考光る. よってここではわが国の市眅はち蜜拈よび採取はち蜜に ついて減压乾燥法および屈折率法によって水分を測定し
比較検討した結果について報告する。

\section{試料および実験方法}

1. 試料 : 昭和 42 年末に東京都区内て購入した市販は ち蜜29種類および採取はち蜜 3 種類を使用した。密閉容 器中のはち蜜を $40^{\circ}$ の温湯に浸漬し, 完全飞融解したの ちに冷却し十分に振り混ぜたのちに試料を採取する。

2. 水分の測定方法

a 減圧乾燥法 : アルミニウム製のふた付き秤量管に 海砂 2 号を $15 \mathrm{~g}$ はかり取り，恒量としたのちにはち蜜 を約 $1.5 \mathrm{~g}$ 採取し, 正確に科量したのちに $60^{\circ}, 10 \mathrm{mmHg}$ の条件で恒量になるまで乾燥して水分を求めた。

$\mathrm{b}$ 属折率法：アダゴ製作所製アッべ屈折計（光源装

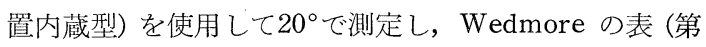
1 表）により，比例計算により小数第 2 位まで求めた。

c 統計処理 : 相関係数標準偏差拈よび温度補正係数 はとれぞれ下記の式によって算出した。

（i） 減圧乾燥法捄よび屈折率法による水分の相関係 数

$$
r=\frac{\sum x_{i} y_{i}-\sum x_{i} \sum y_{i} / N}{\sqrt{\left\{\sum x_{i}{ }^{2}-\frac{\left(\sum x_{i}\right)^{2}}{N}\right\}\left\{\sum y_{i}{ }^{2}-\frac{\left(\sum y_{i}\right)^{2}}{N}\right\}}}
$$

ただし $r:$ 相関係数， $x_{i}$ : 減圧乾燥法による水分 $(\%)$, $y_{i}$ : 属折率法による水分 $(\%), N$ : 試料数

(ii) 回婦からの標準偏差

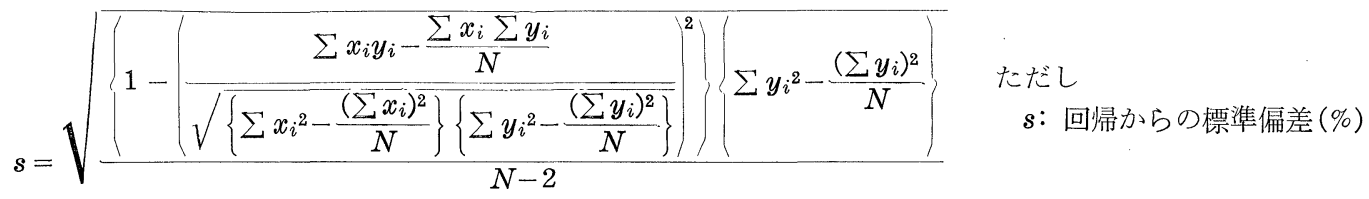

*1 国立衛生試験所 : 東京都世田谷区上用賀 1-18-1

*2 東京家政大学: 東京都板橋区加賀 1 丁目 
第 1 表 Wedmore の水分算定表

\begin{tabular}{|c|c|c|c|c|c|}
\hline $\begin{array}{c}\text { 屈折率 } \\
\left(20^{\circ}\right)\end{array}$ & $\begin{array}{c}\text { 水 分 } \\
(\%)\end{array}$ & $\begin{array}{c}\text { 屈折率 } \\
\left(20^{\circ}\right)\end{array}$ & 水 $(\%)$ & $\begin{array}{c}\text { 屈折率 } \\
\left(20^{\circ}\right)\end{array}$ & $\begin{array}{l}\text { 水 分 } \\
(\%)\end{array}$ \\
\hline 1.5044 & 13.0 & 1.4951 & 16.6 & 1.4860 & 20.2 \\
\hline 1.5038 & 13.2 & 1.4946 & 16.8 & 1.4855 & 20.4 \\
\hline 1.5033 & 13.4 & 1.4940 & 17.0 & 1.4850 & 20.6 \\
\hline 1.5028 & 13.6 & 1.4935 & 17.2 & 1.4845 & 20.8 \\
\hline 1.5023 & 13.8 & 1.4930 & 17.4 & 1.4840 & 21.0 \\
\hline 1.5018 & 14.0 & 1.4925 & 17.6 & 1.4835 & 21.2 \\
\hline 1.5012 & 14.2 & 1.4920 & 17.8 & 1.4830 & 21.4 \\
\hline 1.5007 & 14.4 & 1.4915 & 18.0 & 1.4825 & 21.6 \\
\hline 1.5002 & 14.6 & 1.4910 & 18.2 & 1.4820 & 21.8 \\
\hline 1.4997 & 14.8 & 1.4905 & 18.4 & 1.4815 & 22.0 \\
\hline 1.4992 & 15.0 & 1.4900 & 18.6 & \multirow{8}{*}{$\begin{array}{l}\text { こに } \\
\text { の応 } \\
\text { 間じ } \\
\text { はて } \\
\text { 必作 } \\
\text { 要成 }\end{array}$} & 22.2 \\
\hline 1.4987 & 15.2 & 1.4895 & 18.8 & & 22.4 \\
\hline 1.4982 & 15.4 & 1.4890 & 19.0 & & 22.6 \\
\hline 1.4976 & 15.6 & 1.4885 & 19.2 & & 22.8 \\
\hline 1.4971 & 15.8 & 1.4880 & 19.4 & & 23.0 \\
\hline 1.4966 & 16.0 & 1.4875 & 19.6 & & 23.2 \\
\hline 1.4961 & 16.2 & 1.4870 & 19.8 & & 23.4 \\
\hline 1.4956 & 16.4 & 1.4865 & 20.0 & & 23.6 \\
\hline
\end{tabular}

注 : $20^{\circ}$ 以上で測定する場合には $1^{\circ}$ について $0.000 こ 3 を$ 加える

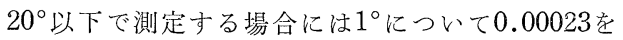
減ずる

(iii） 差の標準偏差

$$
\sigma_{y x}=\sqrt{\frac{\sum\left(y_{i}-x_{i}\right)^{2}-\frac{\sum\left(y_{i}-x_{i}\right)^{2}}{N}}{N-2}}
$$

ただし $\sigma_{y x}$ ：屈折率法と減王乾燥による水分の差の慓 準偏差 $(\%)$

(iv) 温度補正係数

$$
a=\frac{\sum x_{n} y_{n}-\frac{\sum x_{n} \sum y_{n}}{N}}{\sum x_{n}{ }^{2}-\frac{\left(\sum x_{n}\right)^{2}}{N}}
$$

ただし $x_{n}: 20 ， 22 ， 24 ， \cdots \cdots, 38$ 扤よび $40^{\circ}$

$$
y_{n}: x_{n} \text { に掠忷る屈折率 }
$$

\section{実 験 成 績}

市販はち蜜29種類掞よび採取はち蜜 3 種類について水 分を测定した結果は第 2 表に示す通りである. 水分の範 囲は減圧乾燥法では14.79 20.04\%，屈折率法では 17.04 21.56\%の值が得られた。ここで注目すべきこと は全般的に屈折率法の方が減圧乾燥法よりも高い值が得 られて打り，その差は平均 $1.83 \%$, 多いものになると （市販はち蜜 No. 6) 4 \%以上にも達することが認められ る.これを統計処理した結果は両法による水分の相関係

\begin{tabular}{|c|c|c|c|c|}
\hline 試 & 料 & $\begin{array}{c}\text { A. 減 压 } \\
\text { 乾 燥 法 } \\
(\%)\end{array}$ & $\begin{array}{l}\text { B. 屈折 } \\
\text { 率法 } \\
(\%)\end{array}$ & $\mathrm{B}$ と $\underset{(\%)}{\mathrm{A} の}$ \\
\hline 市販はち蜜 & No. 1 & 18.27 & 19.68 & 1.41 \\
\hline " & No. 2 & 17.47 & 18.64 & 1.17 \\
\hline " & No. 3 & 16.59 & 17.88 & 1.29 \\
\hline " & No. 4 & 17.53 & 19.00 & 1.47 \\
\hline " & No. 5 & 16.93 & 18.00 & 1.07 \\
\hline " & No. 6 & 15.80 & 19.88 & 4.08 \\
\hline " & No. 7 & 16.17 & 17.44 & 1.27 \\
\hline " & No. 8 & 18.01 & 19.76 & 1.75 \\
\hline " & No. 9 & 17.67 & 19.44 & 1.77 \\
\hline " & No. 10 & 15.65 & 19.32 & 3.67 \\
\hline in & No. 11 & 16.69 & 18.24 & 1.55 \\
\hline " & No. 12 & 15.85 & 17.32 & 1.47 \\
\hline " & No. 13 & 15.72 & 17.40 & 1.68 \\
\hline " & No. 14 & 17.26 & 18.88 & 1.62 \\
\hline$" \prime$ & No. 15 & 16.68 & 18.48 & 1.80 \\
\hline " & No. 16 & 17.40 & 18.24 & 0.84 \\
\hline " & No. 17 & 18.43 & 21.08 & 2.65 \\
\hline$" \prime$ & No. 18 & 15.93 & 17.84 & 1.91 \\
\hline " & No. 19 & 16.92 & 19.16 & 2.24 \\
\hline " & No. 20 & 16.37 & 17.44 & 1.07 \\
\hline " & No. 21 & 17.57 & 19.04 & 1.47 \\
\hline$"$ & No. 22 & 19.37 & 19.92 & 0.55 \\
\hline$" \prime$ & No. 23 & 17.02 & 19.04 & 2.02 \\
\hline " & No. 24 & 20.04 & 21.56 & 1.52 \\
\hline$" 1$ & No. 25 & 17.85 & 20.96 & 3.11 \\
\hline " & No. 26 & 18.33 & 19.20 & 0.87 \\
\hline " & No. 27 & 19.43 & 19.88 & 0.45 \\
\hline$"$ & No. 28 & 14.79 & 17.04 & 2.25 \\
\hline$"$ & No. 29 & 15.48 & 19.00 & 3.52 \\
\hline 採取はち蜜 & No. 1 & 17.41 & 20.24 & 2.83 \\
\hline$" \prime$ & No. 2 & 15.84 & 17.40 & 1.56 \\
\hline$" \prime$ & No. 3 & 15.47 & 18.00 & 2.53 \\
\hline $\begin{array}{l}\text { 市販品等 } \\
32 \text { 種 }\end{array}$ & & 17.06 & 18.89 & 1.83 \\
\hline
\end{tabular}

第 2 表 減圧乾燥法および屈折率法によるはち蜜の 水分の測定成績

数 0.7479 , 回帰からの標準偏差 $0.79 \%$, 差の標準偏差 $0.85 \%$ であった. な扣, 日本薬局方注解7によれば局方 八チミツの水分は10 12\% と示されているが市販拈よび 採取はち蜜の測定結果ではそのように水分の低いものは 認められなかった。つぎに屈折率法に括ける温度補正係 数の妥当性を調べるために $20 \sim 40^{\circ}$ の間で 2 度間隔で測 定し, 温度と屈折率の回帰式を求め, そのかたむきを第 3 表にまとめて示した. $20^{\circ}$ 未満の温度補正係数の検討 ははち蜜が凝固して正確に屈折率を測定できない場合が 多いので省略した。本表より温度補正係数の実測値は採 
第 3 表 実測值より求めた温度補正倸数

\begin{tabular}{|c|c|c|c|c|c|}
\hline 種 & 類 & $\begin{array}{l}\text { 温度 } \\
\text { 補正係数 }\end{array}$ & 種 & 類 & $\begin{array}{l}\text { 温度 } \\
\text { 補正係数 }\end{array}$ \\
\hline 市 販 & No. 1 & 0.00020 & 市 販 & No. 17 & 0.00020 \\
\hline 虽 & No. 2 & 0.00020 & b & No. 18 & 0.00023 \\
\hline " & No. 3 & 0.00023 & " & No. 19 & 0.00021 \\
\hline " & No. 4 & 0.00019 & "I & No. 20 & 0.00020 \\
\hline " & No. 5 & 0.00019 & " & No. 21 & 0.00022 \\
\hline " & No. 6 & 0.00019 & " & No. 22 & 0.00022 \\
\hline "I & No. 7 & 0.00022 & " & No. 23 & 0.00022 \\
\hline " & No. 8 & 0.00018 & " & No. 24 & 0.00018 \\
\hline " & No. 9 & 0.00025 & " & No. 25 & 0.00022 \\
\hline " & No. 10 & 0.00017 & " & No. 26 & 0.00014 \\
\hline " & No. 11 & 0.00021 & " & No. 27 & 0.00018 \\
\hline " & No. 12 & 0.00026 & " & No. 28 & 0.00018 \\
\hline " & No. 13 & 0.00020 & " & Nò. 29 & 0.00017 \\
\hline " & No. 14 & 0.00020 & $\begin{array}{l}\text { 採 取 } \\
\text { 汇ち蜜 }\end{array}$ & No. 1 & 0.00021 \\
\hline " & No. 15 & 0.00023 & " & No. 2 & 0.00021 \\
\hline$"$ & No. 16 & 0.00024 & " & No. 3 & 0.00022 \\
\hline
\end{tabular}

注 : $20 \sim 40^{\circ}, 2^{\circ}$ 間隔で測定

取はち蜜は0.00021〜0.00022であって，Wedmore によ って示された值とほとんど差はないが，市販はち蜜では 0.00014 0.00026の範囲に変動することが羿められる.

Wedmore の示した值 0.00023 との最大差は0.00009であ りこれは $10^{\circ}$ の温度差で約 $0.2 \%$ の水分の差に相当す る.

\section{考察ならびに結論}

市販はち蜜29種および值接養蜂家において採取したは ち蜜 3 種類を使用して減圧乾燥法および屈折率法により 水分を求めた結果について比較した。 その結果は，一般
に減圧乾燥法は屈折率法にくらべて高い值を示し, 両者 の相関係数は 0.7479 , 差の標準偏差は $0.85 \%$ でった. 減圧乾燥法の方がこのように低い值を得られる理由とし ては，乾燥の途中で表面に皮膜が形成され，内部に包含 された水分が完全に飛散できないためではないかとも推 定される．減圧乾燥法と屈折率法といずれがすぐれてい るかを一概に断定することはできないが，FAO/WHO 暫定規格6)では屈折率法によって測定した值をもって水 分と定めているので，その意味からいえばわが国の国内 検査も屈折率法に統一して找く方が望ましいということ ができる。な括 $\mathrm{FAO} / \mathrm{WHO}$ 暫定規格6)では，水分はと 一スはら蜜 (heather honey) 拈よびクローバーはら蜜 (clover honey) では23\%以下，その他のはち蜜では21\% 以下と定められて和り，この点わが国のはち蜜は水分に 関しては規格に示された範囲内であることが認められ た.

文 献

1) Association of Official Agricultural Chemists: "Official Methods of Analysis of A. O. A.C." 10th ed p. 504 (1965).

2) H. D. Chataway: Canad. J. Res. 6, 540 (1932).

3) J. E. Eckert, H. W. Allinger: Bull. Univ. Calif. Agr. Exp. Sta. No. 631 (1939).

4) J. A. Torrent: Rev. Asoc. Bioquim. Argent. 14, 1 (1949).

5) E. B. Wedmore: Bee World 36, 197 (1955).

6) 慶田雅洋, 白鳥つや子, 川城 嚴：食衛誌. 9, 502 (1968).

7) 日本公定書協会：“第七改正日本薬局方第二部解 説書”p. 420 (1967) 広川書店. 